\title{
TEK wt Allele
}

National Cancer Institute

\section{Source}

National Cancer Institute. TEK wt Allele. NCI Thesaurus. Code C52222.

Human TEK wild-type allele is located within 9p21 and is approximately $121 \mathrm{~kb}$ in length.

This allele, which encodes angiopoietin-1 receptor protein, is involved in angiogenesis, endothelial cell proliferation and differentiation and endothelial cell patterning during vascular morphogenesis. Defects and deficiencies in TEK are associated with venous malformations. 